\title{
Salt stress induced damages on the photosynthesis of physic nut young plants
}

\author{
Evandro Nascimento da Silva ${ }^{1}$; Rafael Vasconcelos Ribeiro ${ }^{2}$; Sérgio Luiz Ferreira-Silva ${ }^{1}$; \\ Ricardo Almeida Viégas ${ }^{3}$; Joaquim Albenisio Gomes Silveira ${ }^{1 *}$ \\ ${ }^{1}$ UFC - Depto. de Bioquímica e Biologia Molecular, C.P. 6020 - 60451-970 - Fortaleza - CE, Brasil.

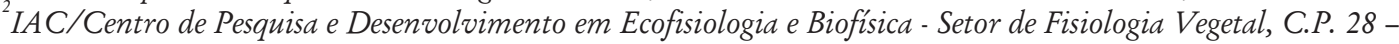 \\ 13012-970 - Campinas - SP, Brasil. \\ ${ }^{3}$ UFPB - Depto. de Engenharia Florestal, C.P. 64 - 58700-970 - Patos - PB, Brasil. \\ *Corresponding author <silveira@ufc.br>
}

\begin{abstract}
Salinity is a major limiting factor to crop productivity in the world especially in semiarid regions. The aim of this study was to evaluate the photosynthetic resistance of Jatropha curcas (L.) young plants subjected to salt stress. The experiment was carried out in a completely randomized design with treatments in a $2 \times 3$ factorial: two $\mathrm{NaCl}$ levels $\left(0\right.$ and $\left.100 \mathrm{mmol} \mathrm{L}^{-1}\right)$ and three harvest times: 7 and 14 days of salt exposure and three days of recovery. Leaf $\mathrm{Na}^{+}$and $\mathrm{Cl}^{-}$concentrations and the $\mathrm{K}^{+} / \mathrm{Na}^{+}$ratios, after seven days of salt exposure, did not reach ionic toxic levels, suggesting that the $\mathrm{NaCl}$-induced osmotic effects prevailed over the ionic ones. Under this condition, the salt stress caused reduction in leaf gas exchange parameters, such as $\mathrm{CO}_{2}$ fixation, stomatal conductance and transpiration. In contrast, salt stress did not change the photochemical efficiency of photossystem II. Conversely, after 14 days of treatment, $\mathrm{Na}^{+}$and $\mathrm{Cl}$ ions reached very high concentrations, up to toxic levels in leaves. Under such conditions, both leaf gas exchange and photochemistry suffered strong impairment probably caused by ionic toxicity. The recovery treatment for $3 \mathrm{~d}$ did not significantly decrease the leaf salt concentrations and no improvement was observed in the photosynthetic performance. Physic nut young plants are sensitive to high $\mathrm{NaCl}$-salinity conditions, with high leaf $\mathrm{Na}^{+}$and $\mathrm{Cl}^{-}$concentrations, low $\mathrm{K}^{+} / \mathrm{Na}^{+}$ratio and great photosynthetic damages due to stomatal and biochemical limitations.
\end{abstract}

Key words: Jatropha curcas, chlorophyll fluorescence, gas exchange, ionic toxicity, salinity

\section{Danos causados por estresse salino sobre a fotossíntese de plantas jovens de pinhão-manso}

\begin{abstract}
RESUMO: A salinidade é um dos principais fatores que limitam a produtividade das culturas no mundo principalmente em regiões semiáridas. Avaliou-se a resistência da fotossíntese de plantas jovens de pinhãomanso (Jatropha curcas L.) submetidas ao estresse salino. O experimento foi realizado em delineamento inteiramente casualizado com tratamentos em fatorial $2 \times 3$ : duas concentrações de $\mathrm{NaCl}\left(0\right.$ e $\left.100 \mathrm{mmol} \mathrm{L}^{-1}\right)$ e três tempos de avaliação (7 e 14 dias de exposição e três dias de recuperação). As concentrações de $\mathrm{Na}^{+}$e $\mathrm{Cl}^{-}$ e a relação $\mathrm{K}^{+} / \mathrm{Na}^{+}$nas folhas, após sete dias de exposição ao sal, não indicaram níveis tóxicos, sugerindo os efeitos osmóticos induzidos pelo $\mathrm{NaCl}$ prevaleceram sobre as causas iônicas. Sob essas condições, o estresse salino causou redução nos parâmetros de trocas gasosas, como fixação de $\mathrm{CO}_{2}$, condutância estomática e transpiração, mas ao contrário, não alterou a eficiência fotoquímica do fotossistema II. Após 14 dias de tratamento, os íons salinos atingiram concentrações muito elevadas nas folhas, provavelmente atingindo níveis tóxicos. Em tais condições, as trocas gasosas e a atividade fotoquímica sofreram forte redução causada pelo estresse iônico. $\mathrm{O}$ tratamento de recuperação não induziu queda intensa nas concentrações dos íons salinos nas folhas e nenhuma melhoria foi observada no desempenho fotossintético. Plantas jovens de pinhão manso são sensíveis a condições de salinidade elevada por $\mathrm{NaCl}$, mostrando altas concentrações de $\mathrm{Na}^{+}$e $\mathrm{Cl}^{-}$, baixa razão $\mathrm{K}^{+} / \mathrm{Na}^{+}$e danos fotossintéticos intensos causados tanto por limitações estomáticas como por limitações bioquímicas.

Palavras-chave: Jatropha curcas, fluorescência da clorofila, trocas gasosas, toxicidade iônica, salinidade
\end{abstract}

\section{Introduction}

Salinity adversely affects plant growth and development, with nearly $20 \%$ of the world cultivated area and about half of the world irrigated lands being affected by salt stress (Sairam and Tyagi, 2004). This problem is more relevant in semiarid regions with low rainfall and high evaporative demand, which strongly contribute to in- crease soil salinization (Viégas et al., 2001). In these regions, the problem of soil secondary salinization is exacerbated by the use of low quality water associated with inadequate techniques of soil management (Ferreira-Silva et al., 2009).

The accumulation of salt ions in plants can cause osmotic stress, ionic toxicity and induce nutritional deficiencies (Munns, 2002). When $\mathrm{Na}^{+}$and $\mathrm{Cl}^{-}$ions reach 
high concentrations in leaves, they cause impairment in both biochemical and photochemical processes of photosynthesis (Munns and Tester, 2008). In addition to these physiological disturbances, abiotic factors such as excess of the salts (Cavalcanti et al., 2007) and heavy metals can trigger secondary stresses as the oxidative stress due to accumulation of reactive oxygen species (Gratão et al., 2005).

The physic nut (Jatropha curcas) grows in marginal areas where important crop species are not able to survive (Francis et al., 2005). Besides, it presents high economic potential due to its seed oil quality, which can be converted into biodiesel by the industry (Silva et al., 2009a). Although this species had shown satisfactory yield under constraining conditions of semiarid regions such as drought and high temperature, the plant physiological responses to salinity are not yet well known, especially in terms of key process like the photosynthesis.

This study was designed to evaluate the photosynthesis tolerance of physic nut young plants to salt stress. Changes in leaf gas exchange, photochemistry activity, and salt stress indicators (leaf $\mathrm{Na}^{+}$and $\mathrm{Cl}^{-}$concentrations and $\mathrm{K}^{+} / \mathrm{Na}^{+}$ratios) were measured after 7 and 14 days of salt stress and 3-d recovery.

\section{Material and Methods}

The experiment was carried out under greenhouse conditions, localized in the Universidade Federal do Ceará, Fortaleza, Ceará, Brazil ( $3^{\circ} 44^{\prime} \mathrm{S}, 38^{\circ} 33^{\prime} \mathrm{W}$, at sea level), where the environmental conditions were: minimum and maximum mean air temperature of 24 and $36^{\circ} \mathrm{C}$, respectively; mean air relative humidity of $65 \%$; maximum photosynthetic photon flux density (PPFD) of approximately $700 \mu \mathrm{mol} \mathrm{m} \mathrm{m}^{-2}$. Jatropha curcas L. seeds, genotype FT-2, were previously selected taking into account the seed size and weight. Eight days after germination in sand, seedlings were transferred to plastic pots (2 L), containing Hoagland and Arnon (1950) nutrient solution ( $\mathrm{pH}$ 6.0) with one-forth strength in the first week and full strength afterwards.

The nutrient solution was supplied with $100 \mathrm{mmol}$ $\mathrm{L}^{-1} \mathrm{NaCl}$ and then plants were subjected to this stressful treatment during 14 days. The $\mathrm{NaCl}$ was added gradually $\left(50 \mathrm{mmol} \mathrm{NaCl} \mathrm{L} \mathrm{d}^{-1}\right)$ into solution in order to avoid osmotic shock. The treatment with nutrient solution in absence of $\mathrm{NaCl}$ was taken as control. At the end of two weeks of treatment, the salt-stressed plants were returned to control conditions for three days. In a previous experiment, a three-day period was sufficient for the full recovery of physic nut young plants subjected to $50 \mathrm{mmol} \mathrm{L}^{-1} \mathrm{NaCl}$.

Leaf gas exchange was measured with an infrared gas analyzer (LCi, ADC, Hoddesdonm, UK), operating in open system and with air flow of $200 \mathrm{~mL} \mathrm{~min}^{-1}$. Measurements of leaf $\mathrm{CO}_{2}$ assimilation rate (A), transpiration (E), stomatal conductance (gs) and intercellular $\mathrm{CO}_{2}$ concentration (Ci) were taken. The instantaneous carboxilation efficiency (A/Ci) was calculated (Zhang et al., 2001).

The chlorophyll fluorescence was evaluated with a modulated fluorometer (FMS2, Hansatech, King's Lynn, $\mathrm{UK})$. Minimum ( $\mathrm{Fo})$, maximum $(\mathrm{Fm})$ and maximum variable $(\mathrm{Fv}=\mathrm{Fm}-\mathrm{Fo})$ fluorescence intensities were sampled under steady-state conditions in dark-adapted $(30 \mathrm{~min})$ leaves. In addition, measurements were also taken under light-adapted conditions, being referred as Fo' (minimum) and Fm' (maximum). The Fo' signal was measured after PSI excitation by far-red light. The fluorescence signal under light-adapted conditions before the saturation pulse is referred as $F_{S}$ ' and the variable fluorescence signal under light conditions is $\Delta \mathrm{F}=\mathrm{Fm}$ '-Fs'.

The following photochemical variables were calculated: maximum $(\mathrm{Fv} / \mathrm{Fm})$ and actual $(\Delta \mathrm{F} / \mathrm{Fm})$ quantum yield of primary photochemistry. Apparent electron transport rate $\left(\mathrm{ETR}=\Delta \mathrm{F} / \mathrm{Fm}^{\prime} \times \mathrm{PPFD} \times 0.5 \times 0.84\right)$, photochemical $\left[\mathrm{qP}=(\mathrm{Fm}\right.$ '-Fs $\left.) /\left(\mathrm{Fm}^{\prime}-\mathrm{Fo}^{\prime}\right)\right]$ and non-photochemical $\left.\left[\mathrm{NPQ}=(\mathrm{Fm}-\mathrm{Fm})^{\prime}\right) / \mathrm{Fm}^{\prime}\right]$ quenching (Rohácek, 2002). For ETR calculation, 0.5 was used as the fraction of excitation energy distributed to PSII and 0.84 as the fraction of the incoming light absorpted by leaves (Schreiber et al., 1998). Fo' is the basal fluorescence yield measured after PSI excitation by far-red light. The ratio ETR/A was calculated to estimate the use of electrons in other processes not related to the photosynthetic $\mathrm{CO}_{2}$ assimilation rate (Ribeiro et al., 2009). Therefore, an increase in ETR/A indicates that more electrons are driven to other sinks (e.g., photorespiration, nitrogen metabolism or Mehler reaction), suggesting a stressful condition.

Leaf gas exchange and chlorophyll fluorescence were measured simultaneously, in fully expanded and mature leaves of plants exposed to $25^{\circ} \mathrm{C}$ and PPFD of $590 \mu \mathrm{mol}$ $\mathrm{m}^{-2} \mathrm{~s}^{-1}$ supplied by an external light source. Those measurements were taken after 7-d and 14-d of treatment $(0$ and $100 \mathrm{mmol} \mathrm{L}^{-1} \mathrm{NaCl}$ ), and repeated again three days after returning plants to the nutrient solution without the presence of $\mathrm{NaCl}$.

At the end of experiment, leaves were sampled, frozen and stored at $-80^{\circ} \mathrm{C}$. After lyophilization, samples were placed into hermetically closed tubes containing deionized water and heated under water-bath at $100^{\circ} \mathrm{C}$ for $1 \mathrm{~h}$. The extracts were then filtered and used for determination of $\mathrm{Na}^{+}$and $\mathrm{K}^{+}$contents by flame photometry. The $\mathrm{Cl}^{-}$content was determinate through titration with $\mathrm{AgNO}_{3}$ as described by Silveira et al. (2009).

The experiment was arranged in a completely randomized design, with two factors: $\mathrm{NaCl}(0$ and $100 \mathrm{mmol}$ $\mathrm{L}^{-1}$ ); time (seven and 14 days of salt stress and three days of recovery). Data were subjected to analysis of variance and mean from four replicates were compared by the Tukey test at the 0.05 level of confidence.

\section{Results and Discussion}

Leaves of physic nut young plants treated with $\mathrm{NaCl}$ $\left(100 \mathrm{mmol} \mathrm{L}{ }^{-1}\right)$ were affected by the $\mathrm{Na}^{+}, \mathrm{Cl}^{-}$and $\mathrm{K}^{+}$con- 
centrations compared to control plants (Table 1). After seven days of treatment, the $\mathrm{Na}^{+}$and $\mathrm{K}^{+}$concentrations reached values around 603 and $581 \mathrm{mmol}\left(\mathrm{kg} \mathrm{DM}^{-1}\right.$ respectively, while the $\mathrm{K}^{+} / \mathrm{Na}^{+}$ratio was reduced from 5.40 to 0.96 in stressed plants. In spite of the $\mathrm{Na}^{+}$accumulation associated with a reduction in $\mathrm{K}^{+}$concentration, and consequent decrease in $\mathrm{K}^{+} / \mathrm{Na}^{+}$ratio, in the treated plants, the saline condition was not sufficient to induce an ionic stress and a great disturbance in the leaf ion homeostasis, taken as basis the $\mathrm{Na}^{+}$and $\mathrm{K}^{+}$concentrations. In fact, Silva et al. (2009b) observed that toxicity symptoms in physic nut leaves appeared only when the leaf $\mathrm{K}^{+} / \mathrm{Na}^{+}$ratio is lower than 0.50 .

After seven days of treatment with $100 \mathrm{mmol} \mathrm{L}^{-1}$ $\mathrm{NaCl}$, the leaf $\mathrm{Cl}^{-}$content was just $326 \mathrm{mmol}(\mathrm{kg} \mathrm{DM})^{-1}$ (Table 1). This concentration represents only $54 \%$ of that noticed for the $\mathrm{Na}^{+}$concentration, evidencing that $J$. curcas is a species more excluder of $\mathrm{Cl}^{-}$than $\mathrm{Na}^{+}$. The stress imposed by $\mathrm{NaCl}$ was predominantly osmotic over the ionic effects. This evidence is consistent with the results obtained by Silva et al. (2009a) working with several $\mathrm{NaCl}$ levels under experimental conditions similar to those employed in this current study. In addition, this species actually has a high affinity for $\mathrm{Na}^{+}$and/or greater ability to exclude $\mathrm{Cl}^{-}$ions from roots and leaves (Silva et al., 2009b).

After 14-d of exposure to salt stress, the $\mathrm{Na}^{+}$and $\mathrm{Cl}^{-}$ concentrations reached very high levels, possibly achieving toxic values. The $\mathrm{Na}^{+}$and $\mathrm{Cl}^{-}$concentrations were about 1,721 and $1,498 \mathrm{mmol}(\mathrm{kg} \mathrm{DM})^{-1}$ respectively. These concentrations of $\mathrm{Na}^{+}$and $\mathrm{Cl}^{-}$ions are able to trigger salt toxicity symptoms in physic nut leaves such as leaf chlorosis followed by necrotic areas (Silva et al., $2009 \mathrm{~b}$ ), as shown in the Figure 1. Corroborating these observations, the leaf $\mathrm{K}^{+}$concentration decreased strongly in salt-stressed plants, varying from 1,071 (control) to $423 \mathrm{mmol}(\mathrm{kg} \mathrm{DM})^{-1}$. As a consequence, the $\mathrm{K}^{+} /$ $\mathrm{Na}^{+}$ratio was reduced from 5.0 to 0.24 , evidencing clearly that after 14-d of exposure the salinity induced great disturbances in the $\mathrm{K}^{+}-\mathrm{Na}^{+}$ionic homeostasis (Munns and Tester, 2008).

The salt-induced osmotic effects after 7-d and the toxic ionic effects after 14-d of salt exposure were evidenced by the appearance of visual symptoms in physic nut leaves (Figure 1). Indeed, after 7-d of treatment the leaves exhibited minor senescence symptoms while the leaves showed drastic toxicity visual symptoms after 14$\mathrm{d}$ as indicated by intense necrotic areas. These symptoms persisted even after the $\mathrm{NaCl}$ removal from the nutrient medium (recovery). After 3-d recovery, the $\mathrm{Na}^{+}$ and $\mathrm{Cl}^{-}$concentrations in the pre-stressed plants decreased by $15 \%$ and $17 \%$ only, respectively while that the $\mathrm{K}^{+} / \mathrm{Na}^{+}$ratio was not changed, in comparison to the 14-d stressed plants (Table 1). Thus, most J. curcas plants suffered an osmotic stress after 7-d. However, a strong ionic stress was established in physic nut leaves in the following seven days, i.e., after 14-d of exposure to $\mathrm{NaCl}$.

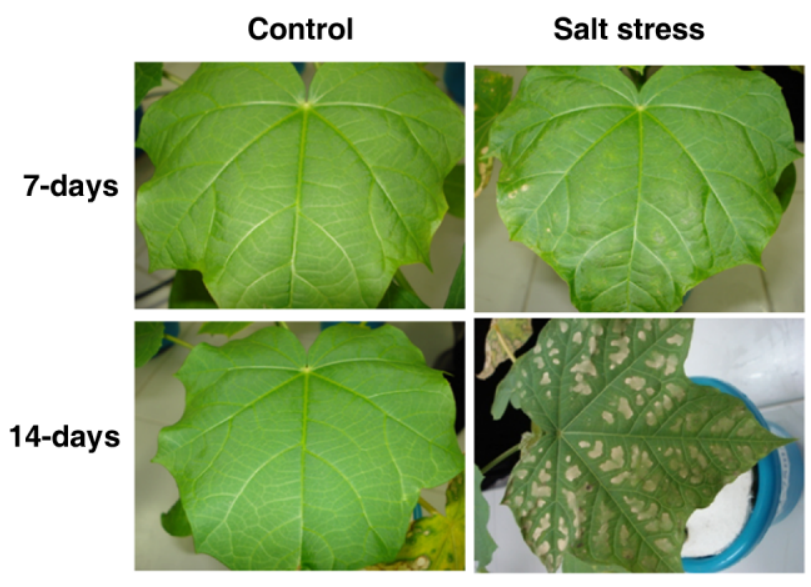

Figure 1 - Leaf toxicity symptoms in Jatropha curcas young plants cultivated in absence and presence of $\mathrm{NaCl}$ $\left(100 \mathrm{mmol} \mathrm{L}^{-1}\right)$ during stress period.

Table 1 - Concentrations of $\mathrm{Na}^{+}, \mathrm{Cl}^{-} \mathrm{e} \mathrm{K}^{+}$and $\mathrm{K}^{+} / \mathrm{Na}^{+}$ratio in leaves of physic nut young plants cultivated in absence and presence of $\mathrm{NaCl}\left(100 \mathrm{mmol} \mathrm{L}^{-1}\right)$ during $7-\mathrm{d}$ and $14-\mathrm{d}$ and after 3-d of recovery. Values are means of four replicates.

\begin{tabular}{lcccl}
\hline \multirow{2}{*}{ Parameter } & \multirow{2}{*}{$\mathrm{NaCl}$} & \multicolumn{3}{c}{ Days after treatment } \\
\cline { 3 - 5 } & $\mathrm{mmol} \mathrm{L}-1$ & & 14 \\
\hline $\mathrm{Na}^{+}$ & 0 & $133 \mathrm{Bb}$ & $215 \mathrm{Ab}$ & $215 \mathrm{Ab}$ \\
$\mathrm{mmol}(\mathrm{kg} \mathrm{DM})^{-1}$ & 100 & $603 \mathrm{Ca}$ & $1,721 \mathrm{Aa}$ & $1,458 \mathrm{Ba}$ \\
\hline $\mathrm{Cl}^{-}$ & 0 & $102 \mathrm{Bb}$ & $147 \mathrm{Ab}$ & $139 \mathrm{Ab}$ \\
$\mathrm{mmol}(\mathrm{kg} \mathrm{DM})^{-1}$ & 100 & $326 \mathrm{Ca}$ & $1,498 \mathrm{Aa}$ & $1,240 \mathrm{Ba}$ \\
\hline $\mathrm{K}^{+}$ & 0 & $716 \mathrm{Ba}$ & $1,071 \mathrm{Aa}$ & $1,123 \mathrm{Aa}$ \\
$\mathrm{mmol}(\mathrm{kg} \mathrm{DM})^{-1}$ & 100 & $581 \mathrm{Ab}$ & $423 \mathrm{Cb}$ & $496 \mathrm{Bb}$ \\
\hline $\mathrm{K}^{+} / \mathrm{Na}^{+}$ratio & 0 & $5.4 \mathrm{Aa}$ & $5.0 \mathrm{Aa}$ & $5.2 \mathrm{Aa}$ \\
& 100 & $0.96 \mathrm{Ab}$ & $0.24 \mathrm{Bb}$ & $0.34 \mathrm{Bb}$ \\
\hline
\end{tabular}

Values represented by the same upper case letters, between time of treatment and same lower case letters, into of each time of treatment are different (Tukey, $p<0.05$ ). 
Overall, after the first days of salt exposure glycophyte plants display an osmotic response and that after some weeks the ionic component of the salinity is predominant (Munns and Tester, 2008).

The leaf $\mathrm{CO}_{2}$ assimilation rate was strongly reduced in plants exposed to salt stress compared to control ones. Plants submitted to $\mathrm{NaCl}$ had $23 \%$ and $85 \%$ reductions after 7 and 14-d of treatment, respectively (Figure 2A). The transpiration rate was reduced in $39 \%$ and $84 \%$ (Figure $2 \mathrm{~B}$ ), the stomatal conductance by $80 \%$ and $97 \%$ (Figure $2 \mathrm{C}$ ) and the intercellular $\mathrm{CO}_{2}$ concentration by $23 \%$ and $47 \%$ (data not shown) after 7 and $14-d$ of treatment,
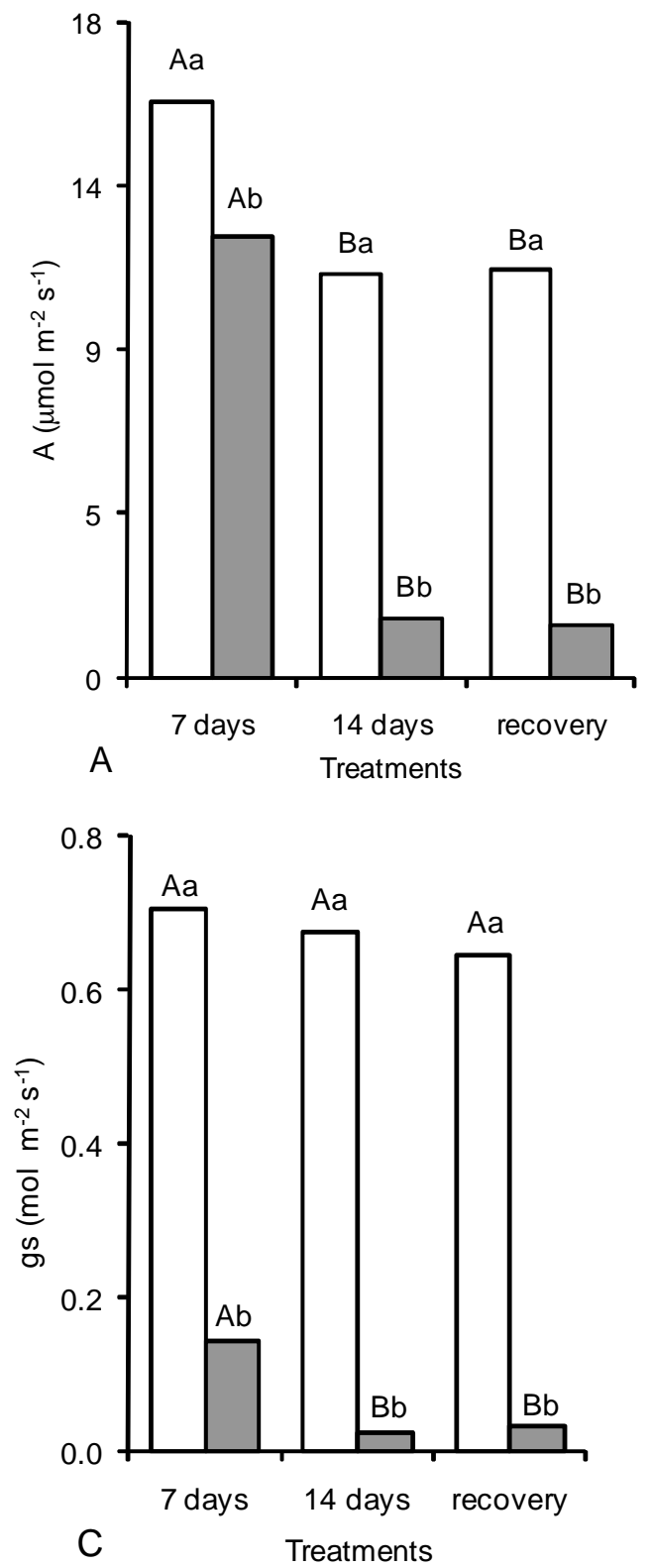

respectively. In contrast, the instantaneous carboxylation efficiency, estimated by the A/Ci ratio (Figure 2D), remained unchanged after $7-\mathrm{d}$ of treatment but it was strongly reduced (73\%) after 14-d of exposure to $\mathrm{NaCl}$. Interestingly, after 3-d of recovery the A/Ci ratio did not change as compared to stressed plants (Figure 2D).

The reduction of photosynthesis after seven days of salt treatment was caused only by a stomatal limitation, i.e. reduced $\mathrm{CO}_{2}$ availability to carboxylation, while both the stomatal and biochemical limitations were observed after 14 days of treatment. As expected, the negative effects caused by salt stress on the leaf gas exchange
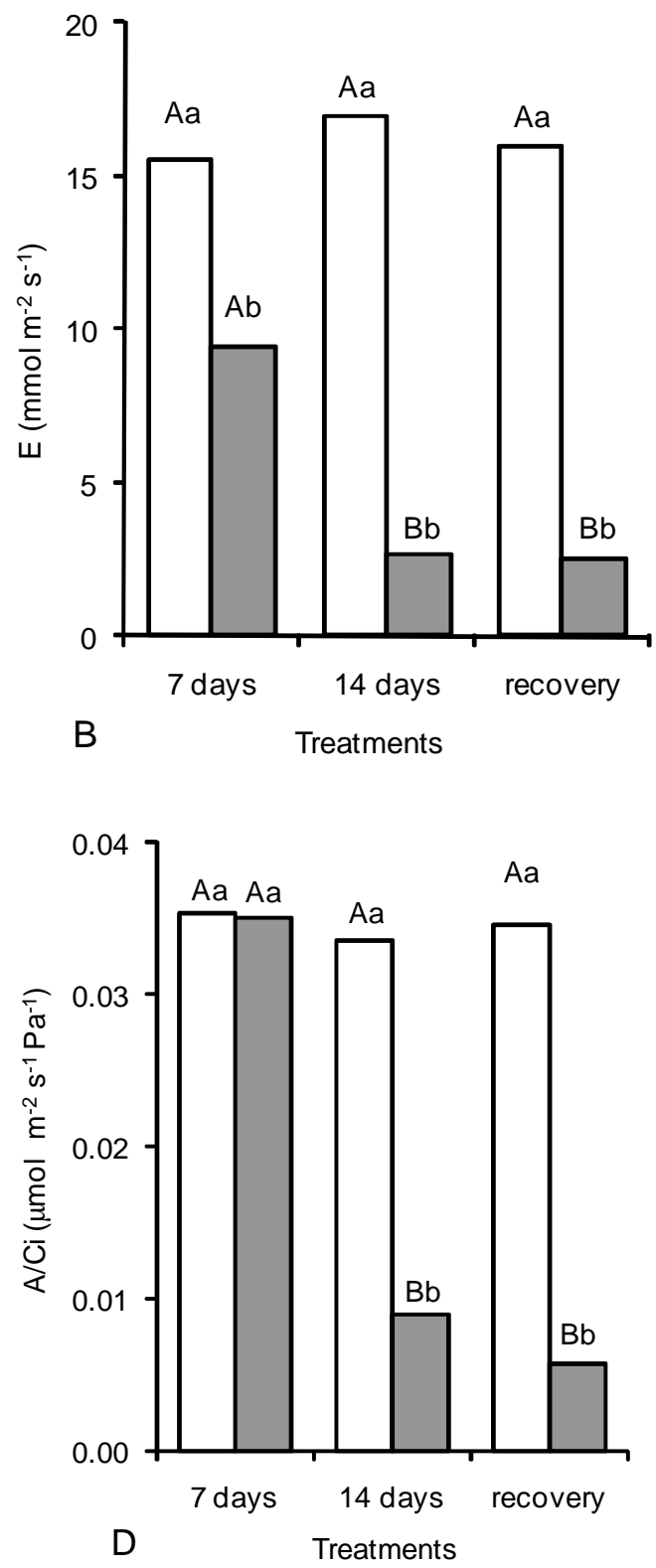

Figure 2 - Leaf $\mathrm{CO}_{2}$ assimilation rate (A), transpiration (B), stomatal conductance (C) and instantaneous carboxilation efficiency (D) in Jatropha curcas young plants cultivated in absence and presence of $\mathrm{NaCl}\left(100 \mathrm{mmol} \mathrm{L}^{-1}\right)$ during $7-\mathrm{d}$ and $14-\mathrm{d}$ and after 3 -d of recovery. White bars represent control plants and gray bars represent stressed plants. Values are means of four replicates. Values represented by the same upper case letters, between time of treatment and same lower case letters, into of each time of treatment are not different (Tukey, $p<0.05$ ). 
variables were progressively increased as the time of salt exposure increased. In addition, no improvement in the photosynthesis was observed after the salt removal (recovery treatment), suggesting that after 14-d of treatment irreversible damage on the photosynthesis occurred provably due to ionic toxicity caused in the chloroplasts (López-Climent et al., 2008).

The decrease of photosynthesis associated with low stomatal conductance in plants subjected to saline conditions (Figure 2) is in accordance to Meloni et al. (2003), who observed impairment in the photosynthetic efficiency of cotton cultivars exposed to 50 and $100 \mathrm{mmol}$ $\mathrm{L}^{-1} \mathrm{NaCl}$. On the other hand, decreases in intercellular $\mathrm{CO}_{2}$ concentration and $\mathrm{A} / \mathrm{Ci}$ ratio also indicate that salt
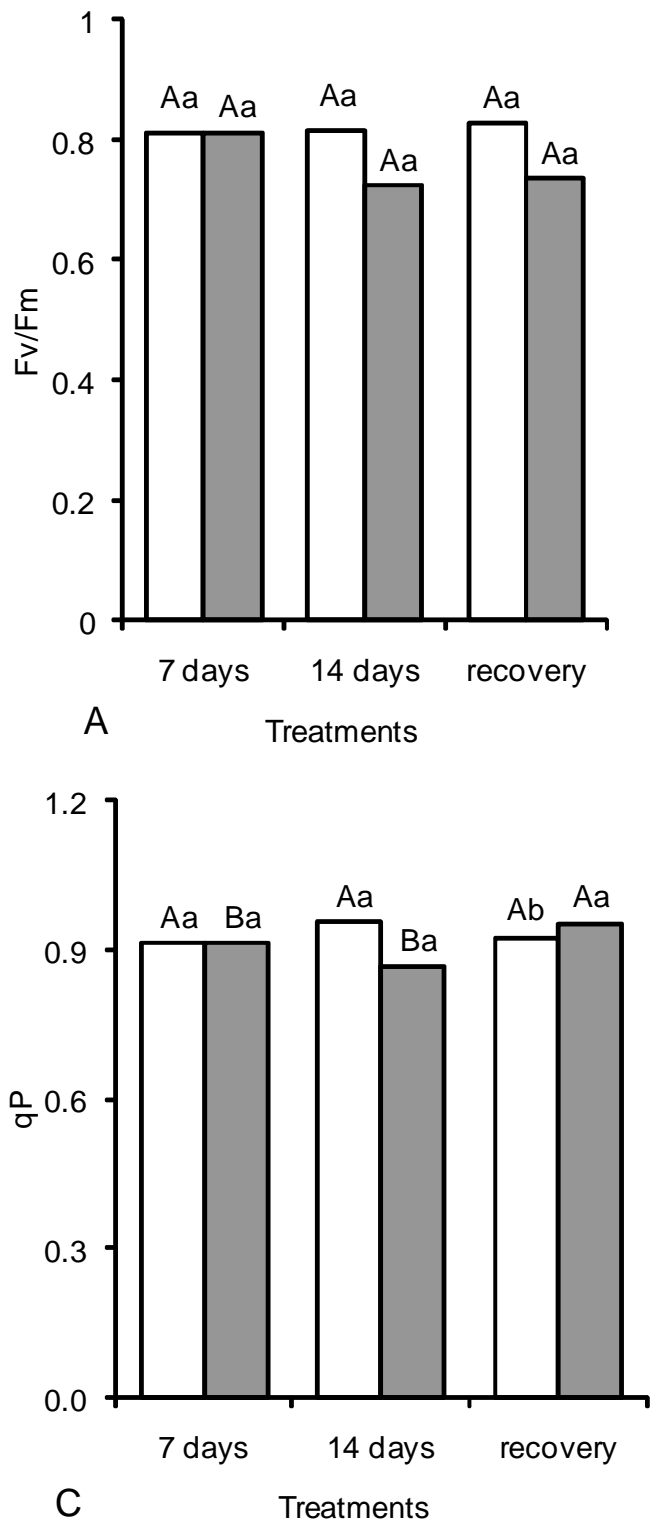

stress affected the photosynthesis by metabolic limitation. Reductions of $\mathrm{A} / \mathrm{Ci}$ ratio are probably associated with a decrease of Rubisco carboxylase activity, which occurred in parallel with $\mathrm{Na}^{+}$and $\mathrm{Cl}^{-}$intense accumulation in leaf tissues (Table 1). Thus, the reduction of photosynthesis may, at least in part, be a direct effect of $\mathrm{Na}^{+}$and $\mathrm{Cl}^{-}$ions, as observed in sorghum (Netondo et al., 2004) and orange (López-Climent et al., 2008) plants.

Regarding to photochemistry effects, maximum quantum yield (Fv/Fm) was not affected by salinity, whereas the actual quantum yield of primary photochemistry $(\Delta \mathrm{F} / \mathrm{Fm}$ ') decreased $(39 \%)$ after $14-\mathrm{d}$ of exposure to $\mathrm{NaCl}$ (Figure 3A,B). The photochemical quenching $(\mathrm{qP})$ was not affected by salt stress, while the non-
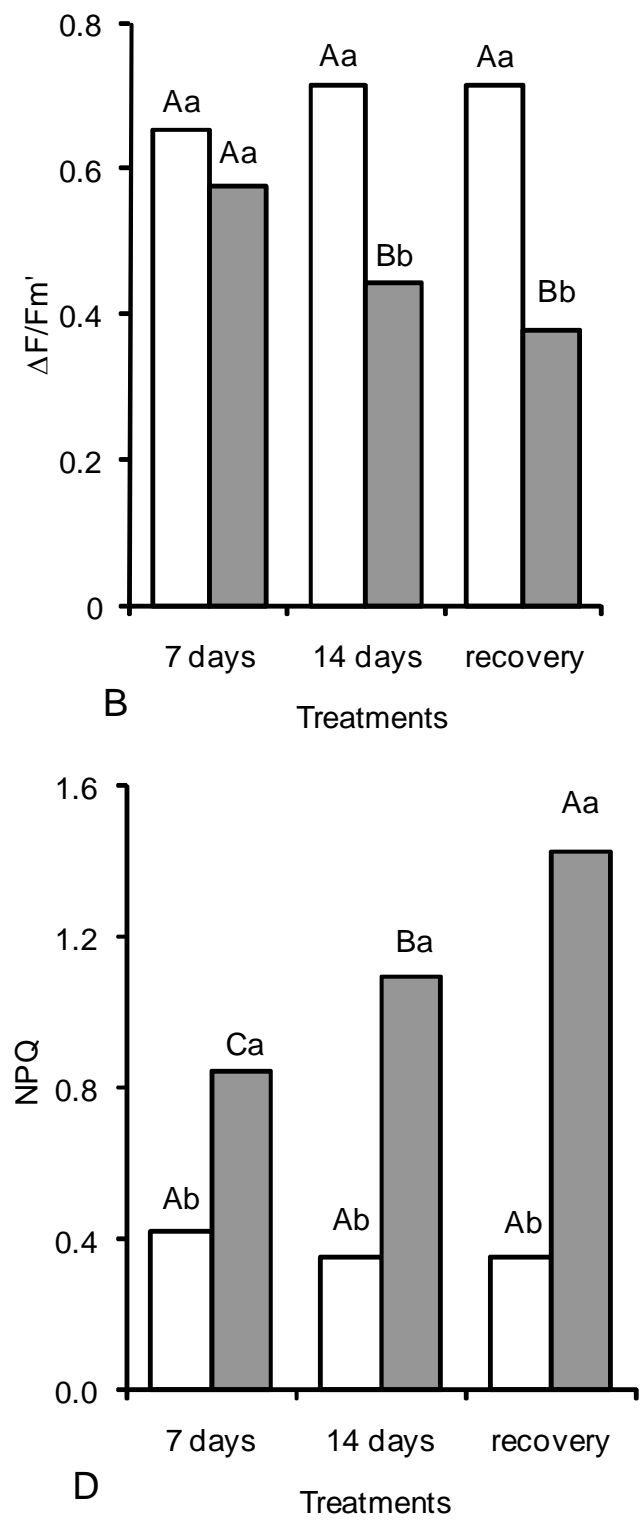

Figure 3 - Maximum (A) and actual (B) quantum yield of primary photochemistry, photochemical (C) and non-photochemical (D) quenching in Jatropha curcas young plants cultivated in absence and presence of $\mathrm{NaCl}\left(100 \mathrm{mmol} \mathrm{L}{ }^{-1}\right)$ during $7-\mathrm{d}$ and 14 $\mathrm{d}$ and after 3-d of recovery. White bars represent control plants and gray bars represent stressed plants. Values are means of four replicates. Values represented by the same upper case letters, between time of treatment and same lower case letters, into of each time of treatment are not different (Tukey, $p<0.05$ ). 
photochemical quenching (NPQ) increased in plants subjected to salt stress (Figure 3C,D). The increase of NPQ was already significant after seven days of treatment and progressively increased after 14-d of salt stress (Figure 3D).

Interestingly, this photochemical parameter increased in the recovery treatment. The reduction of $\Delta \mathrm{F} /$ Fm' accompanied by a decrease in the apparent electron transport rate (data not shown) in the stressed plants differs from results reported by $\mathrm{Lu}$ et al. (2002), who did not observe effects of salt stress in photochemical reactions of $S$. salsa leaves. Impairments in photochemistry of plants exposed to salinity may be related to possible damages in primary electron acceptors, such as plastoquinone pool (Foyer and Noctor, 2000). In addition, the continuous increase of NPQ during stress and recovery treatments suggest the activation of a protective mechanism for dissipation of excessive energy not used in photochemical reactions (Ribeiro et al., 2009; Rohácek, 2002). However, this protective defense was not sufficient to avoid oxidative and irreversible damage after 14-d of treatment, as suggested by the toxicity symptoms in leaves (Figure 1). Our data reveal a reasonable photochemical activity even under ionic stress, which was not compatible with the photosynthetic rates (Figures 2 and 3). In fact, full inhibition of PSII photochemistry occurs only under severe oxidative damage (Chagas et al., 2008).

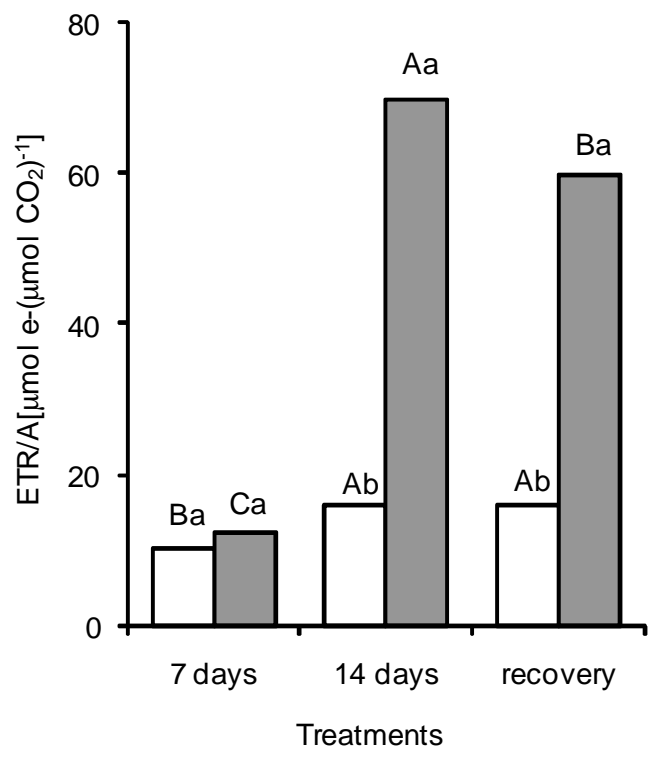

Figure 4 - Ratio between apparent electron transport rate and $\mathrm{CO}_{2}$ assimilation (ETR/A, in C) in Jatropha curcas young plants cultivated in absence or presence of $\mathrm{NaCl}\left(100 \mathrm{mmol} \mathrm{L}^{-1}\right)$ during 7-d and 14-d and after 3 -d of recovery. White bars represent control plants and gray bars represent stressed plants. Values are means of four replicates. Values represented by the same upper case letters, between time of treatment and same lower case letters, into of each time of treatment are not different (Tukey, $p<0.05$ ).
After 14-d under salt stress, plants showed ETR/A ratio 4-fold higher than the control. This difference was maintained even after the recovery period (Figure 4). The increase in ETR/A ratio represents an imbalance between the electron flow and the $\mathrm{CO}_{2}$ assimilation during photosynthesis, which is frequently associated with increases in oxygenase activity of Rubisco and might represent an electron flow to other physiological processes rather than to $\mathrm{CO}_{2}$ assimilation reactions (Baker et al., 2007; Ribeiro et al., 2009). Thus, the occurrence of increases in ETR/A and decreases in $\mathrm{A} / \mathrm{Ci}$ might indicate a loss of photosynthetic efficiency in physic nut plants under salinity, especially in the ionic phase of salt stress.

The accumulation of toxic ions $\left(\mathrm{Na}^{+}\right.$and $\left.\mathrm{Cl}^{-}\right)$accompanied by decreases in $\mathrm{K}^{+}$concentration and severe photosynthetic damages indicate that physic nut young plants are sensitive to high salinity caused by $\mathrm{NaCl}$. The absence of any recovery in photosynthesis, after three days of salt removing, also indicates that high $\mathrm{Na}^{+}$and $\mathrm{Cl}^{-}$leaf concentrations might cause acute damages on the photochemical and gas exchange of the photosynthesis.

\section{Conclusion}

Physic nut young plants are sensitive to high salinity, showing high leaf $\mathrm{Na}^{+}$and $\mathrm{Cl}^{-}$concentrations and very low $\mathrm{K}^{+} / \mathrm{Na}^{+}$ratios, after 14 days of exposure to 100 mmol L ${ }^{-1} \mathrm{NaCl}$. Under this condition, the salt-induced ionic toxicity effects are capable to induce acute photosynthetic damages (photochemistry and gas exchange) due to stomatal and biochemical limitations.

\section{Acknowledgements}

To CNPq, CAPES and "Fundação Cearense de Apoio ao Desenvolvimento Científico e Tecnológico" (FUNCAP) for financial support. J.A.G.S. and R.V.R. are $\mathrm{CNPq}$ researchers and E.N.S. and S.L.F.S. hold CNPq fellowships. The authors gratefully acknowledge the Tamanduá Farm Institute, Santa Terezinha-PB (Brazil), for supplying of physic nut seeds.

\section{References}

Baker, N.R.; Harbinson, J.; Kramer, D.M. 2007. Determining the limitations and regulation of photosynthetic energy transduction in leaves. Plant, Cell and Environment 30: 11071125.

Cavalcanti, F.R.; Oliveira, J.T.A.; Martins-Miranda, A.S.; Viégas, R.A.; Silveira, J.A.G. 2007. Superoxide dismutase, catalase and peroxide activities do not confer protection against oxidative damage in salt-stressed cowpea leaves. Journal of Plant Physiology 163: 563-571.

Chagas, R.M.; Silveira, J.A.G.; Ribeiro, R.V.; Vitorrelo, V.A.; Carrer, H. 2008. Photochemical damage and comparative performance of superoxide dismutase and ascorbate peroxidase in sugarcane leaves exposure to paraquat-induced oxidative stress. Pesticide Biochemistry and Physiology 80: 181-188.

Ferreira-Silva, S.L.; Voigt, E.L.; Viégas, R.A.; Paiva, J.R.; Silveira, J.A.G. 2009. Influence of rootstocks on the resistance of cashew plantlets to salt stress. Pesquisa Agropecuária Brasileira 44: 361 367. (in Portuguese, with abstract in English). 
Foyer, C.H.; Noctor, R. 2000. Oxygen processing in photosynthesis: regulation and signaling. New Phytologist 146: 359-388.

Francis, G. Edinger, R. Becker, K. 2005. A concept for simultaneous wasteland reclamation, fuel production, and socio-economic development in degraded areas in India: Need, potential and perspectives of Jatropha plantations. Nature Resources Forum 29: 12-24.

Gratão, P.L.; Polle, A.; Lea, P.J.; Azevedo, R.A. 2005. Making the life of heavy metal-stressed plants a little easier. Functional Plant Biology 32: 481-494.

Hoagland, D.R.; Arnon, D.I. 1950. The water culture method for growing plants without soil. University of California, Berkeley, CA, USA.

López-Climent, M.F.; Arbona, V.; Pérez-Clemente, R.M.; GómezCadenas, A. 2008. Relationship between salt tolerance and photosynthetic machinery performance in citrus. Environmental and Experimental Botany 62: 176-184.

Lu, C.; Qiu, N.; Lu, Q. 2002. Does salt stress lead to increased susceptibility of photosystem II to photoinhibition and changes in photosynthetic pigment composition in halophyte Suaeda salsa grown outdoors? Plant Science 63: 1063-1068.

Meloni, D.A.; Oliva, M.A.; Martinez, C.A.; Cambraia, J. 2003. Photosynthesis and activity of superoxide dismutase, peroxidase and glutathione reductase in cotton under salt stress. Environmental and Experimental Botany 49: 69-76.

Munns, R. 2002. Comparative physiology of salt and water stress. Plant, Cell and Environment 25: 239-250.

Munns, R.; Tester, M. 2008. Mechanisms of salinity tolerance. Annual Review of Plant Biology 59: 651-681.

Netondo, G.W.; Onyango, J.C.; Beck, E. 2004. Sorghum and salinity. II. Gas exchange and chlorophyll fluorescence of sorghum under salt stress. Crop Science 44: 806-811.

Ribeiro, R.V.; Machado, E.C.; Santos, M.G.; Oliveira, R.F. 2009. Photosynthesis and water relations of well-watered orange plants as affected by winter and summer conditions. Photosynthetica 47: 215-222.
Rohácek, K. 2002. Chlorophyll fluorescence parameters: the definitions, photosynthetic meaning, and mutual relationships. Photosynthetica 40: 13-29.

Sairam, R.K.; Tyagi, A. 2004. Physiology and molecular biology of salinity stress tolerance in plants. Current Science 86: 407-421.

Schreiber, U.; Bilger, W.; Hormann, H.; Neubauer, C. 1998. Chlorophyll fluorescence as a diagnostic tool: basics and some aspects of practical relevance. In: Raghavendra, A.S., ed. Photosynthesis: a comprehensive treatise. Cambridge University Press, Cambridge, MA, USA.

Silva, E.N.; Silveira, J.A.G.; Fernandes, C.R.R.; Lima, C.S.; Viégas, R.A. 2009a. Contribution of organic and inorganic solutes to osmotic adjustment of physic nut under salinity. Pesquisa Agropecuária Brasileira 44: 437- 445.

Silva, E.N.; Silveira, J.A.G.; Fernandes, C.R.R.; Dutra, A.T.B.; Aragão, R.M. 2009b. Ion uptake and growth of physic nut under different salinity levels. Revista Ciência Agronômica 40: 240-246.

Silveira, J.A.G.; Sandro, S.A.M.; Lima, J.P.M.S.; Viégas, R.A. 2009. Roots and leaves display contrasting osmotic adjustment mechanisms in response to $\mathrm{NaCl}$-salinity in Atriplex nummularia. Environmental and Experimental Botany 66: 1-8.

Viégas, R.A.; Silveira, J.A.G.; Lima Júnior, A.R.; Queiroz, J.E.; Fausto, M.J.M. 2001. Effects of NaCl-salinity on growth and inorganic solute accumulation in young cashew plants. Revista Brasileira de Engenharia Agrícola e Ambiental 5: 216-222.

Zhang, S.; Li, Q.; Ma, K.; Chen, L. 2001. Temperature-dependent gas exchange and stomatal/nonstomatal limitation to $\mathrm{CO} 2$ assimilation of Quercus liaotungensis under midday higher irradiance. Photosynthetica 39: 383-388.

Received September 23, 2009

Accepted April 27, 2010 